\title{
DESIGNING OF AUTONOMOUS HEAT SUPPLY SYSTEMS AND OPTIMIZATION OF ENERGY RESOURCES AT THEIR EXPLOITATION
}

Stenin Al. - Dr. Sc., Professor of the Department of Technical Cybernetics at Igor Sikorsky Kiev Polytechnic Institute, Kyiv, Ukraine.

Pas'ko V. - PhD, Associate Professor of the Department of Technical Cybernetics at Igory Sikorsky Kiev Polytechnic Institute, Kyiv, Ukraine.

Drozdovych I. - PhD, Research Associate at Institute of Telecommunications and Global Information, Space National Academy of Sciences of Ukraine, Kyiv, Ukraine.

\begin{abstract}
Relevance. To solve most of the tasks facing the housing and communal services of the country, it is necessary to create and implement new efficient energy-saving technologies and units, the development of which will solve the problem of reducing heat consumption and metal consumption when using individual heat points in district heating systems.

Goal. Increase in the efficiency of autonomous heat supply systems (AHSS) for housing and communal services objects. Ensuring effective means of analyzing complex systems and processes in multi-circuit heat exchangers for heating and hot water supply systems.

Method. To achieve this goal, a systematic approach was applied to the analysis of thermal and hydraulic processes occurring in the autonomous heat supply systems and modeling of heat exchange processes in multi-circuit heat exchangers. To solve the boundary value problem, an iterative procedure is proposed. On the experimental stand, the model is explored, experimental data are obtained.

Results. The dependence of the coolant consumption in the circuits and the amount of heat are established theoretically and experimentally. An iterative procedure is developed. Studies were carried out on the basis of the experimental stand. Based on the results of the experiments, a nomogram of thermal calculation of a multi-circuit heat exchanger was constructed.

Conclusions. The experiments carried out on the experimental stand developed by the authors of the experiment fully confirm the correctness of the theoretical results obtained and provide an effective tool for constructing industrial samples.

KEYWORDS: autonomous heat supply system, heat exchangers of a coiled type, tank-accumulator, basic design parameters, optimization of energy resources, experimental stand.
\end{abstract}

\author{
ABBREVIATIONS \\ HW - hot water supply; \\ AHSS - automated heat supply systems; \\ TA - tank-accumulator; \\ HE - heat-exchanging unit; \\ MHUT - a multi-loop unit with the accumulating \\ tank; \\ ITP - individual thermal point; \\ HAU - heating-accumulating unit.
}

\section{NOMENCLATURE}

Tenv - the environmental temperature;

$\Delta \tau$ - the temperature of the premier contour;

$\tau-$ the time period;

$Q_{i}$ - heat power;

$G_{i}$ - outlet temperature in the $i$-contour;

$c_{i}$ - heat capacities of the incalescent heat carriers in the icontour;

$t_{i}^{I}$ - the temperature at the entry of the i-contour;

$t_{i}^{c p}$-average temperatures of the $i$-contour heat carriers;

$t_{i}^{I I}$ - the temperature at the exit of the $i$-contour;

$F_{i}$ - diameter of the $i$-contour;

$k_{i}$ - heat consumption in the $i$-contour;

$k_{\text {общ }}-$ total heat consumption;
$A_{i}$ - square of the tube cross-section of the heat carrier contour $(i=1)$, heat system contour coil $(i=2)$, hot water supply system coil $(i=3)$, hot water tankaccumulator $(i=4)$.

\section{INTRODUCTION}

Development and improvement of the energy-saving technologies in the modern heat exchanging systems is restrained in many respects by the absence of the calculating method and modern computing complexes allowing to adequately forecast the state of such systems in the whole equipment load range. The list of unsettled issues regarding the improvement of the centralized heat supply systems requires the scientific search and development of the recommendations for their practical application. That is why the work efficiency and heat supply systems exploitation increase at the expense of the new models (units) development resources saving technologies implementation is a highly relevant scientific and technical problem for Ukraine. In this respect, one of the heat exchanging unit prospective models is the model of a heat exchanger of a coiled type with the tankaccumulator patented by one of the authors [1].

In fig. 1 the MHUT cross-section, which heat exchanging processes are investigated in this work, is presented. 


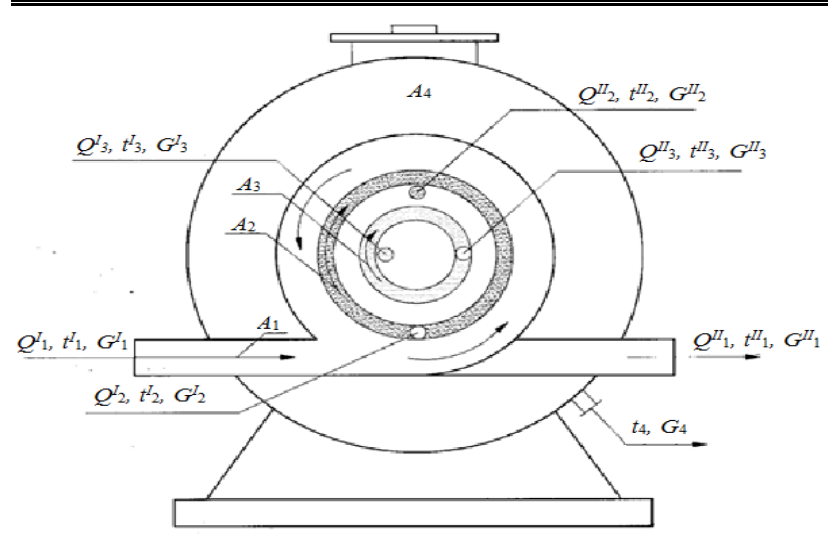

Figure 1 - MHUT of a coiled type cross-section

The MHUT work is realized in the following way: the premier heat carrier enters the HE intertube space, created by the frame and the coiled tubes. Having given its heat through the surface of the heating and hot water supply systems coils and the surface of the tank-accumulator frame goes back to the heat source. The running water heats and enters the hot water supply system coil, where it heats up to $55-60^{\circ} \mathrm{C}$ and afterwards it flows into the accumulating container, from which the water is consumed for the hot water supply needs. The heating water is constantly circulating in the second coil with the help of the noiseless pump.

\section{PROBLEM STATEMENT}

The known parameters in the heat-exchanging unit are temperatures of the hot heat carrier $t_{1}^{I}$ and $t_{1}^{I I}$ at the entry and exit of the heat exchanging unit frame; temperatures of the incalescent heat carriers of the heating contour $t_{2}^{I}$ and $t_{2}^{I I}$ with the consumption $G_{2}$; temperature of the incalescent heat carriers of the third contour of the hot water supply system $t_{3}^{I I}$ and $t_{3}^{I}$ with the consumption $G_{3}$, which flows into the hot water tank-accumulator.

The unknown parameters are the following seven parameters:

- consumption of the premier heat carrier $G_{1}$;

- initial and terminal water temperatures $t_{4}$ in the tankaccumulator;

- water consumption with the TA, entering the hot water supply system according to the daily consumption schedule $G_{4}$;

- diameters of the first, second, third and fourth contours of the heat exchanging unit $F_{1}, F_{2}, F_{3}$ and $F_{4}$. It is necessary to solve the following tasks for the chosen MHUT construction:

- to define the principles of the constructive parameters basic meanings calculation in the fixed work regime;

- to develop the algorithm of the energy resources optimization during the MHUT exploitation.

\section{REVIEW OF THE LITERATURE}

It is known that the most complete evaluation of the created heat exchanger efficiency has to take into consideration the convection, mass, volume and cost characteristics, units and components workability and unification degree indexes, exploitation indexes. Hence, during the analysis of any heat exchangers, it is necessary to take into consideration so many parameters that at first sight there seems to be no use in the analytical solution receiving trial, which might allow getting the desired evaluation. Especially taking into account that the analytical solution of the full Navier-Stokes equation has not been found yet [3].

While creating the new and more effective heat exchangers the aim is to decrease the specific consumption of materials, work, resources, energy, consumable during the work comparing to the existing heat exchangers indexes. The specific consumption for the heat exchanging units is the consumption related to the thermal productivity under the set conditions [4]. Until recently the heat exchanging units calculation has come to the fixed work regimes calculation and finding such parameters as the temperatures average difference, heat transfer coefficients, heat transfer surface and hydraulic bearings [5]. However, during the modern automated autonomous heat supply systems creation, it is necessary to have the quantitative dependencies in the form of mathematical models characterizing both fixed and flexible heat exchanging units work regimes. Partially these issues have been considered in the work [6] in which the scientific foundations of the mathematical description of heat transfer processes in the heat exchanging units multithreaded stage have been developed in the form of the ordinary linear differential equations system as the simplified longitudinal model of the full Navier-Stokes equation. In the article [7], the modelling of the heat exchange process in the intermediate heat exchanger of a coiled type, which is a part of the heat extraction contour of the "UNITERM" reactor unit fulfilled using the hydro and gas dynamical package ANSYS CFX, is considered. The given article is the further development of the works mentioned above oriented towards the AHSS of the housing and communal services.

\section{MATERIALS AND METHODS}

The calculation of the constructive parameters of the heat exchangers of a coiled type for the independent heating and hot water supply systems is based on the thermal balance equation and the heat transfer equation combined solution.

We define the MHUT thermal power for the heating $Q_{2}$ and hot water supply $Q_{3}$ system contours from the formulae:

$$
\begin{aligned}
& Q_{2}=G_{2} \cdot c_{2}\left(t_{2}^{I I}-t_{2}^{I}\right), \\
& Q_{3}=G_{3} \cdot c_{3}\left(t_{3}^{I I}-t_{3}^{I}\right),
\end{aligned}
$$


where $C_{2}$ and $C_{3}$ is the thermal capacity of the heat carriers with the $t_{2}^{c p}$ and $t_{3}^{c p}$ average heat carriers temperatures:

$$
t_{2}^{c p}=\frac{t_{2}^{I I}+t_{2}^{I}}{2} \text { и } t_{3}^{c p}=\frac{t_{3}^{I I}+t_{3}^{I}}{2}
$$

Considering the thermal losses through the external surface of the tank-accumulator we define the premier heat carrier consumption from the formula:

$$
G_{1}=\frac{Q_{2}+Q_{3}}{C_{1}\left(t_{1}^{I I}-t_{1}^{I}\right)} \eta_{\Pi о т}
$$

If the premier heat carrier is the vapor, then the formula (4) becomes:

$$
G_{\Pi}=\frac{Q_{2}+Q_{3}}{\left(i_{\Pi}^{I I}-t_{K}^{I}\right)} \eta_{\Pi о T},
$$

where $\Delta c_{1}$ is the premier heat carrier thermal capacity at the average temperature; $\eta_{\text {loss }}-$ the heat losses through the HE external surface coefficient. At that:

$$
t_{1}^{c p}=0.5\left(t_{1}^{I I}-t_{1}^{I}\right)
$$

$t_{1}{ }^{11}$ - the saturated vapor enthalpy at the Psat pressure; $t_{1}{ }_{1}$ the water enthalpy on the saturation line at the Psat saturation pressure;

Further, we write the thermal balance equations:

- heat exchange between the premier heat carrier and the heating contour heat carrier:

$$
Q_{1-2}=K_{1} \cdot F_{2}\left(t_{1}^{c p}-t_{2}^{c d}\right),
$$

- heat exchange between the premier heat carrier and the hot water system contour heat carrier:

$$
Q_{1-3}=K_{2} \cdot F_{2}\left(t_{1}^{c p}-t_{3}^{c d}\right)
$$

- heat exchange between the premier heat carrier and the water in the HE through the heat exchanger frame:

$$
Q_{1-4}=K_{3} \cdot F_{1}\left(t_{1}^{c p}-t_{4}^{c d}\right)
$$

At that, the average temperatures of the premier warming heat carrier and the heat carriers incalescent in the coils of the heating contour and the hot water supply and the water in the TA are respectively equal:

$$
\begin{aligned}
& t_{1}^{c p}=0.5\left(t_{1}^{I}+t_{1}^{I I}\right), \\
& t_{2}^{c p}=0.5\left(t_{2}^{I}+t_{2}^{I I}\right),
\end{aligned}
$$

$$
\begin{aligned}
& t_{3}^{c p}=0.5\left(t_{3}^{I}+t_{3}^{I I}\right), \\
& t_{4}^{c p}=0.5\left(t_{4}^{I}+t_{4}^{I I}\right),
\end{aligned}
$$

The heat quantity which is perceived by the heat carrier of the heat supply system contour:

$$
Q_{2}=G_{2} \cdot c_{2}\left(t_{2}^{I}+t_{2}^{I I}\right) \text {. }
$$

The heat quantity received by the heat carrier of the hot water supply system contour:

$$
Q_{3}=G_{3} \cdot c_{3}\left(t_{3}^{I I}+t^{I}\right) \text {. }
$$

The heat quantity used for the TA water heating, at the dewatering decrease for the water supply through the heat exchanger frame:

$$
Q_{4}=G_{4} \cdot c_{4}\left(t_{1}^{c p}+t_{4}^{c p}\right) \text {. }
$$

In that way, the unknown parameters calculation is based on the thermal balance equation and the heat transfer equation combined solution:

$$
\left\{\begin{array}{l}
Q_{1-2}=k_{1} \cdot F_{2}\left(t_{1}^{c p}-t_{2}^{c p}\right) \\
Q_{1-3}=k_{2} \cdot F_{3}\left(t_{1}^{c p}-t_{3}^{c p}\right) \\
Q_{1-4}=k_{2} \cdot F_{1}\left(t_{1}^{c p}-t_{4}^{c p}\right) \\
Q_{2}=G_{2} \cdot c_{2}\left(t_{2}^{I}+t_{2}^{I I}\right) \\
Q_{3}=G_{3} \cdot c_{3}\left(t_{3}^{I}+t_{2}^{I I}\right) \\
Q_{4}=G_{4} \cdot c_{4}\left(t_{1}^{c p}+t_{4}^{c p}\right)
\end{array}\right.
$$

where: $\quad t_{1}^{c p}=0.5\left(t_{1}^{I I}-t_{1}^{I}\right), \quad t_{2}^{c p}=0.5\left(t_{2}^{I I}-t_{2}^{I}\right)$, $t_{3}^{c p}=0.5\left(t_{3}^{I I}-t_{3}^{I}\right), \quad t_{4}^{c p}=0.5\left(t_{4}^{I I}-t_{4}^{I}\right) \quad$ the average temperature of the heat carrier in the respective contour.

The equations system (17) is the system of equations with twelve unknown values: $Q_{1-2}, Q_{1-3}, Q_{1-4}, F_{2}$, $F_{3}, F_{1}, G_{2}, t_{2}^{I}, t_{2}^{I I}, G_{4}, Q_{2}, Q_{4}$.

In the given equations the tI2 value can be accepted equal to the $t_{2}$ based on the MHUT construction distinguishing features. Hence, the value $\left(t_{2}^{\mathrm{II}}-t_{2}^{\mathrm{I}}\right)$ must be close to zero. Its deviation from zero may serve as the acceptable simplifications validity measure. If $\left(t_{2}^{I I}-t_{2}^{I}\right)<0$, it is necessary to increase the heat exchanging surface of the MHUT heating contour coil and if $\left.\left(t_{2}^{I I}-t_{2}^{I}\right)\right\rangle 0$, the heat exchanging surface may be left unchanging while the $G_{1}$ premier heat carrier consumption may be decreased. Setting a number of the known constructive parameters it is possible to define the others using the given fixed temperature regimes. The received basic values of the constructive parameters have to answer the total thermal balance equation: 


$$
\left\{\begin{array}{l}
G_{1} \cdot c_{1}\left(t_{1}^{I}-t_{1}^{I I}\right)=G_{2} \cdot c_{2}\left(t_{2}^{I I}-t_{2}^{I}\right)+G_{3} \cdot c_{3}\left(t_{3}^{I I}-t_{3}^{I}\right)+G_{4} \cdot c_{4}\left(t_{4}^{I I}-t_{4}^{I}\right)+G_{4} \cdot c_{4}\left(t_{4}^{I I}-t_{\text {окк }}\right) ; \\
k_{3 a z} \cdot \sum F \cdot \Delta t_{c p}^{3 a z}=k_{1} \cdot F_{2}\left(t_{1}^{c p}-t_{2}^{c p}\right)+k_{2} \cdot F_{3}\left(t_{1}^{c p}-t_{3}^{c p}\right)+k_{3} \cdot F_{1}^{T O}\left(t_{1}^{c p}-t_{4}^{c p}\right)+k_{4} \cdot F_{4}^{T A}\left(t_{4}^{c p}-t_{\text {окp }}\right)
\end{array} .\right.
$$

We shall consider the power inputs optimization at the given AHSS exploitation. The autonomous heat supply system of the private building based on the MHUT is shown in the fig. 2.

In fig. 2 the MHUT with the consecutive joining of the pointed contours coils is shown for the heating and HW contours presentation clearness. However, in the given work the parallel joining of the coils (fig. 3) is considered further as the more effective from the MHUT composition and the heat exchange processes point of view.

Here, $T_{1}^{I}, T_{2}, T_{3}, T_{1}^{I I}, T_{2}^{I I}, T_{3}^{I I}-$ are the temperatures of the warming heat carrier and the heating and HW heat carriers contours at the entry and the exit respectively, $A_{1}, A_{2}, A_{3}-$ are their cross-section squares respectively.

In the given AHSS two main work regimes - the transitional and the fixed - can be distinguished.

The transitional regime. In the given article the MHUT AHSS heating contour outlet to the nominal (fixed) work regime at the presence of the temperature regime in the tank-accumulator and thus in the HW contour is considered. As far as the temperature is associated with the heating contour, the task is to settle the set water temperature value both in it and in the heating contour. It may occur through the coil of the premier heat carrier in the form of the hot liquid from the boiler or the geothermal source; through the coil of the premier heat carrier in the form the heated gas; through the special coil with the built-in electrical spiral.

In any case (except geothermal sources), the AHSS outlet to the set temperature regime requires the energy sources consumption. That is why the optimization from the energy sources consumption in the transitional regime minimization point of view is the important objective.

It is known that the heat transfer process is followed by water mixing process, i.e. recirculation process. Hence, this process can be described by the differential equations system with the delayed argument, which are the simplified model of the Navier-Stokes equations [3,5,9]. At that, the delay value $\tau$ in our case can be defined on the basis of the constructive parameters of the heating contour and the nominal water circulation. As the result, the heating contour structural scheme can be presented in the following way (fig. 4).

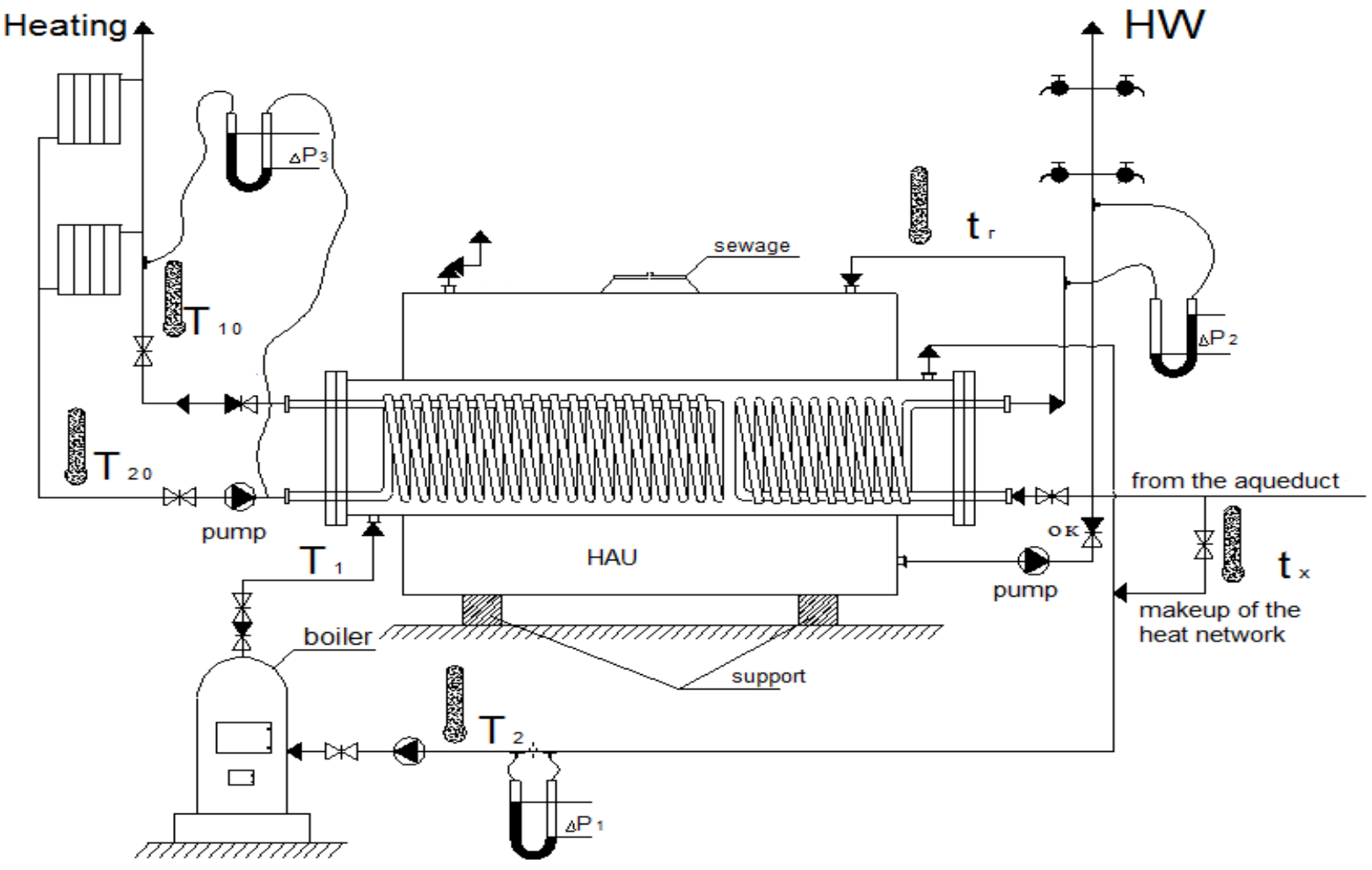

Figure 2 - The autonomous heat supply system of the building based on MHUT 


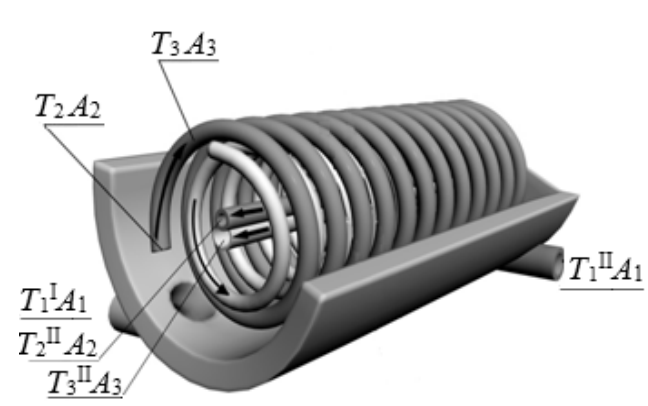

Figure 3 - The parallel joining of the heating and HW contours coils

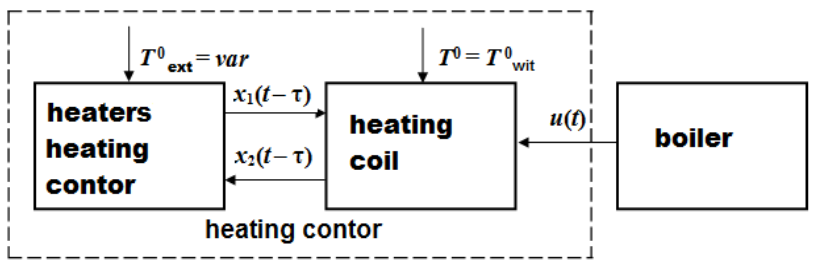

Figure 4 - The heating contour structural scheme

For it, we can write the following differential-residual equations with the afteraction system:

$$
\begin{aligned}
& \frac{d x_{1}(t)}{d t}=k_{1}\left[x_{1}(t)-T^{0}\right]+k_{2}\left[x_{2}(t-\tau)-x_{1}(t)\right], \\
& \frac{d x_{2}(t)}{d t}=k_{u} u_{i}-k_{3}\left[x_{2}(t)-x_{1}(t-\tau)\right]
\end{aligned}
$$

under the set boundary conditions: $x_{1}(t), x_{2}(t)$ is the temperature in the batteries and the coil of the heating contour; $x_{1}(0)=x_{2}(0)=T_{\text {окр }} ; x_{1}(T)=x_{2}(T)=T^{\circ}$

The optimal control objective is to ensure the heating contour temperature outlet to the set value $T^{\circ}$ at the final moment. For the objective setting the cost functional is defined with the expression:

$$
I=\left[x_{1}(T)-T^{0}\right]+\int_{0}^{T} c u_{i}^{2}(t) d t .
$$

Also, we will consider, that the temperature in the tank-accumulator at the time period $[-\tau, 0]$ is equal to the environmental temperature Tenv, which corresponds to the real state of the heating system before the starting. The optimal objective solution for the system (22) is very difficult and impossible in the analytical form because of the afteraction effect. The slack variable method, which allows bringing the initial system with the afteraction to the ordinary differential and transfer equations (to which the known optimization methods are applicable) system is suggested by the authors.

Taking into consideration the aforementioned, we pass from the recording (19) to the recording of the form:

$$
\begin{aligned}
& \frac{d x_{1}(t)}{d t}=-k_{1}\left[x_{1}(t)-T^{0}\right]+k_{2}\left[z_{2}(t)-x_{1}(t)\right], \\
& \frac{d x_{2}(t)}{d t}=k_{u} u_{i}-k_{3}\left[x_{2}(t)-z_{1}(t)\right], \\
& \frac{d y_{1}(t, \theta)}{d t}+k_{4} \frac{d y_{1}(t, \theta)}{d t}=-k_{5}\left[y_{1}(t, \theta)-T^{0}\right] \\
& \frac{d y_{2}(t, \theta)}{d t}+k_{4} \frac{d y_{2}(t, \theta)}{d t}=-k_{5}\left[y_{2}(t, \theta)-T^{0}\right]
\end{aligned}
$$

under the boundary conditions:

$$
\begin{aligned}
& y_{1}(0, \theta)=0, y_{2}(0, \theta)=0, \\
& y_{1}(t, 0)=x_{1}(t), y_{2}(t, 0)=x_{2}(t),
\end{aligned}
$$

where $z_{1}(t)=y_{1}(t, \theta), z_{2}(t)=y_{2}(t, \theta), x_{1}(t), x_{2}(t)-$ is the temperature in the heating radiator and the heating contour coil respectively; $y_{1}(t, \theta) ; y_{2}(t, \theta)-$ is the temperature in the pipelines; $u_{i}=u$ is the equation connected to the energy consumption for the heat carriers temperature change $\left(0 \leq u_{i} \leq u_{\max }\right) ; T^{\circ}$ is the set temperature; $k_{i}$ is the constant. The maximum method is used as the optimization method [10].

Hamiltonians are composed for the equations of the system (29) and (30):

$$
\begin{aligned}
& H_{\psi}=\psi_{0} c u^{2}(t)+\psi_{1}\left[-T^{0}+k_{2}\left(y_{2}(t, \tau)-x_{1}(t)\right)\right]+ \\
& +\psi_{2}\left[k_{u} u_{i}-k_{3}\left(x_{2}(t) y_{2}(t, \tau)\right],\right. \\
& K_{\psi}=-\varphi_{1} k_{5}\left[y_{1}(t, \theta)-T^{0}\right]- \\
& -\varphi_{2} k_{5}\left[y_{2}(t, \theta)-T^{0}\right],
\end{aligned}
$$

where $\psi_{i}, \varphi_{i}$-are auxiliary variables.

In this case, the conjugate equations system and the boundary conditions have the form:

$$
\begin{aligned}
& \frac{\partial \psi_{0}(t)}{\partial t}=0, \frac{\partial \psi_{1}(t)}{\partial t}=\left(k_{1}+k_{2}\right) \psi_{1}(t)-k_{5} \varphi_{1}(t, 0), \\
& \frac{\partial \psi_{2}(t)}{\partial t}=k_{3} \psi_{2}(t)-k_{5} \varphi_{2}(t, 0), \\
& \psi_{0}(T)=-c ; \psi_{1}(T)=-2\left(x_{1}(T)-T^{0}, \psi_{2}(T)=-0 .\right. \\
& \frac{\partial \varphi_{1}}{\partial t}+k_{4} \frac{\partial \varphi_{1}}{\partial \theta}=k_{5} \varphi_{1} ; \frac{\partial \varphi_{2}}{\partial t}+k_{4} \frac{\partial \varphi_{2}}{\partial \theta}=k_{5} \varphi_{2}, \\
& \varphi_{1}(t, \tau)=\frac{k_{3}}{k_{4}} \psi_{2}(t) ; \varphi_{2}(t, \tau)=\frac{k_{2}}{k_{u}} \psi_{1}(t), \\
& \varphi_{1}(T, \theta)=0 ; \varphi_{2}(T, \theta)=0 ; t \in[0, T] ; \theta \in[0, \tau] .
\end{aligned}
$$

As far as the optimal equation has to ensure the hamiltonian maximum, therefore: 


$$
u^{\text {heat }}(t)=\left\{\begin{array}{l}
0, \text { when } \frac{k_{u}}{2 c} \psi_{2}\langle 0, \\
\frac{k_{u}}{2 c}, \text { when } 0<\frac{k_{u}}{2 c} \leq u_{\max }, \\
\left.u_{\max ,} \text { when } \frac{k_{u}}{2 c}\right\rangle u_{\max } .
\end{array}\right\}
$$

To define the trajectory change rule $\psi_{2}$ it is necessary to solve conjointly the auxiliary equations (24), (25) and equations (21), (22) using the optimal equation formula. The combined solution of the stated equations is the boundary-value problem solution. In the common case, such problems solution requires calculus mathematics methods application [8].

In this case, the next iterative procedure can be suggested.

Step 1. To set some initial value $x_{1}(T)$ and calculate $\psi_{1}(T)=2-2\left(x_{1}(T)-T^{0}\right)$.

Step 2. To integrate the conjugate equations system (24) in the reverse time from $t=T$ to $t=0$ and define $\psi_{2}(t)$ and $\psi_{1}(t)$.

Step 3. To define $u(t)$ from (26).

Step 4. Having put the defined value $u(t)$ in (19) and integrated the given system from $t=0$ to $t=T$, to define the new value $x_{1}(T)$.
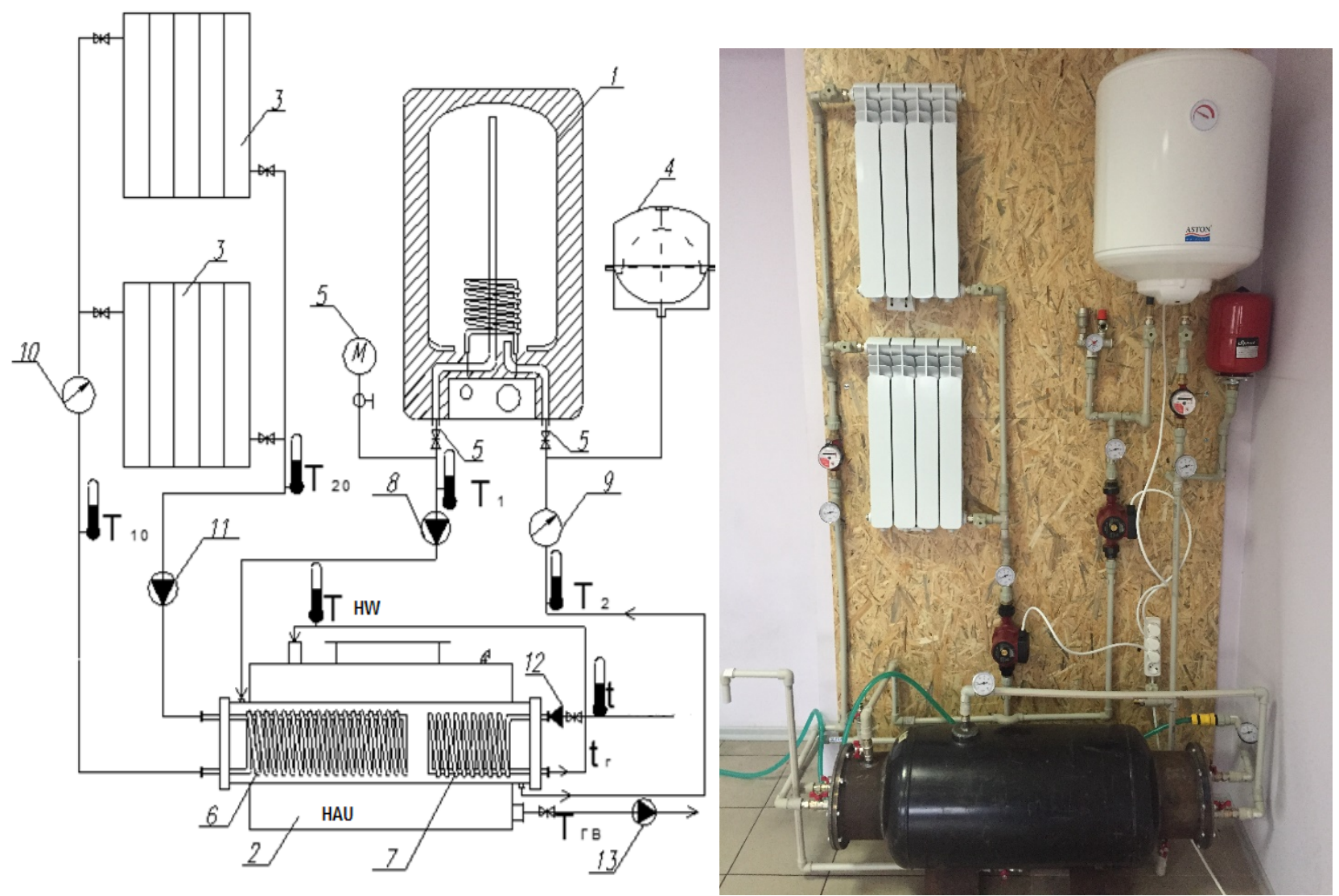

Figure 5 - The MHUT: $\mathrm{a}$ - experimental stand scheme; $\mathrm{b}$ - full-sized model

Step 5. If the defined value $x_{1}(T)$ differs from the one set initially, we pass to step 1 . If they are close (according to the set accuracy degree), the defined decision is optimal.

The fixed regime. It is concluded in the set temperature regime stabilization (maintenance) at the small changes of the environmental temperature and the current volume of the hot water consumption. It is considered that the premier heater temperature is stable and corresponds to the set temperature regimes. The main possibility condition for the heating contour is that the heating time period in the heating contour coil has to be much less than the water circulation time period in this contour. In this case, the temperature regime stabilization is ensured by the circulation pump with the corresponding water circulation speed change. HW supply contour temperature regime is totally defined by the tankaccumulator temperature stability, which in its turn can be ensured both by the constructive feedback, suggested by the authors, and the water consumption automatic compensation. At that, the main condition is that the water heating time period in the HW contour coil, defined from the MHUT dynamic model, has to be much less than the water mixing time period in the tank-accumulator.

\section{EXPERIMENTS}

To carry out the experiments and approve the correctness of the received theoretical results the authors have created the MHUT experimental stand (fig. 5a, b). 
Here: 1 - boiler (Novater.50); 2 tank-accumulator (431.); 3 - radiators; 4 - expansion pneumatic tank (41.); 5 - safety group (manometer, air valve, waste valve $300 \ldots$ ); 6 - heating contour coil; 7 - hot water contour coil; 8 - warming heat carrier circulation pump (Wilo-StarRS25/4); 9 - warming heat carrier flowmeter $\left.\ldots-1.5 \ldots, 90^{\circ} \mathrm{C}, H=1 \ldots, G=1,5 \mathrm{~m}^{3} / \mathrm{h}\right) ; 10-$ heating carrier flowmeter for the heating $(\ldots-1,5 \ldots$, $90^{\circ} \mathrm{C}, H=1 \ldots, G=1,5 \mathrm{~m}^{3} / \mathrm{h}$ ); heating contour circulation pump (Wilo-StarRS25/4); 12 - cold water flowmeter $\left(\ldots 1.5 \ldots, 90^{\circ} \mathrm{C}, H=1 \ldots, \quad G=1.5 \mathrm{~m}^{3} / \mathrm{h}\right) ; 13$ - step-up station; 14 - bimetallic radial thermometer (... 0 $150^{\circ} \mathrm{C}, 2.5 \%$ accuracy class) -7 pieces; $15-$ globe valve $\varnothing 20 \mathrm{~mm}$.

Both coils are placed separately in the MHUT frame, as it is shown in the fig. 5a. The coils heating is arranged from the boiler 1 with the warming heat carrier which is circulating in its contour with the help of the pump 8 , and the consumption is fixed according to the flowmeter 9 indications, the temperature of which may vary within the bounds from $40^{\circ}$ to $90^{\circ} \mathrm{C}$. The water volume increasing at the temperature rising is compensated with the help of the expansion vessel 4 . The secondary heating contour water is heated in the coil 6 and circulates in the heating contour with the help of the pump 11, and the heated water quantity is fixed with the flowmeter 10 . The cold tap water in the hot water contour is heated in the coil 7 with the warming heat carrier from the boiler 1 and flows into the HAU tank-accumulator 2 , from which with the help 12 is forwarded into the hot water supply system of the building with the temperature $50^{\circ}-60^{\circ} \mathrm{C}$. The first, second and third contours heat carriers consumption is regulated with the help of the respective taps 15 , and the total water consumption is fixed with the help of the flowmeters 9, 10, 12 in each separate contour.

\section{RESULTS}

On the basis of the experimental stand, the MHUT research has been carried out for the independent heating system as well as for the hot water supply system. The obtained results are listed in the table 1 , where $\tau$ is the set temperature regimes at the entry and the exit, F, Fheat, Fhw is the coils surface for the heating...hot water supply systems contours and the HE frame, $m$ is the quantity of the consumers. On the basis of the table 1 , a whole range of the temperature dependences for the MHUT energetic balance check has been obtained. In particular, the diagrams (presented in the fig. 6) have been built for the MHUT energetic balance check.

Table 1 - Obtained results

\begin{tabular}{|c|c|c|c|c|c|c|c|c|c|c|c|c|c|}
\hline \multirow[t]{2}{*}{ № } & \multicolumn{3}{|c|}{ Consumption, $\mathrm{kg} / \mathrm{s}$} & \multicolumn{3}{|c|}{ Temperature Drop, } & \multicolumn{3}{|c|}{ Heat Quantity, } & \multirow{2}{*}{$\begin{array}{l}\begin{array}{c}\text { Heat } \\
\text { Coef. }\end{array} \\
\mathrm{K}, \\
\frac{W t}{m \cdot{ }^{\circ} \mathrm{C}}\end{array}$} & \multicolumn{3}{|c|}{ Velocity, $\mathrm{m} / \mathrm{s}$} \\
\hline & $\sum G_{1}^{\prime}, \mathrm{kg} / \mathrm{s}$ & $G_{2}^{\prime}, \mathrm{kg} / \mathrm{s}$ & $\begin{array}{c}G_{3}^{\prime}, \\
\mathrm{kg} / \mathrm{s}\end{array}$ & $\Delta \tau_{1},{ }^{\circ} \mathrm{C}$ & $\Delta t_{2},{ }^{\circ} \mathrm{C}$ & $\Delta t_{3},{ }^{\circ} \mathrm{C}$ & $\begin{array}{l}Q_{1}^{\prime}, \\
\mathrm{kJ} / \mathrm{s}:\end{array}$ & $\begin{array}{l}Q_{2}^{\prime}, \\
\mathrm{kJ} / \mathrm{s}:\end{array}$ & $\begin{array}{l}Q_{3}^{\prime} \\
\mathrm{kJ} / \mathrm{s}\end{array}$ & & $\begin{array}{l}w_{1}^{\prime} \\
\mathrm{m} / \mathrm{s}\end{array}$ & $\begin{array}{c}w_{2}^{\prime}, \\
\mathrm{m} / \mathrm{s}\end{array}$ & $\begin{array}{l}w_{3}^{\prime}, \\
\mathrm{m} / \mathrm{s}\end{array}$ \\
\hline 1 & 2 & 3 & 4 & 5 & 6 & 7 & 8 & 9 & 10 & 11 & 12 & 13 & 14 \\
\hline \multirow{4}{*}{$\begin{array}{l}m=100 \\
m=10\end{array}$} & 4.08 & 2.34 & 1.74 & 80 & 25 & 50 & 1370 & 786 & 584 & & 2.08 & 0.374 & 0.278 \\
\hline & 0.408 & 0.234 & 0.174 & 80 & 25 & 50 & 137 & 78.6 & 58.4 & & 0.408 & 0.491 & 0.354 \\
\hline & & & \multicolumn{9}{|c|}{$F=3,636 \mathrm{~m}^{2} ; \quad F_{O T}=11,63 \mathrm{~m}^{2} ; \quad F_{T B}=4,32 \mathrm{~m}^{2}$} & & \\
\hline & & & & & & & & & & & & & \\
\hline \multirow{5}{*}{ 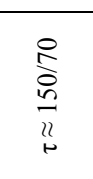 } & 4.08 & 2.34 & 1.74 & 80 & 25 & 50 & 1370 & 786 & 584 & 4702 & 2.080 & 1.194 & 0.888 \\
\hline & 2.04 & 1.17 & 0.87 & 80 & 25 & 50 & 685 & 393 & 292 & 2355 & 1.041 & 0.596 & 0.444 \\
\hline & 1.02 & 0.586 & 0.434 & 80 & 25 & 50 & 343 & 179 & 146 & 1179 & 0.520 & 0.298 & 0.222 \\
\hline & 0.51 & 0.293 & 0.217 & 80 & 25 & 50 & 172 & 98.5 & 73 & 591 & 0.260 & 0.149 & 0.111 \\
\hline & 0.255 & 0.146 & 0.109 & 80 & 25 & 50 & 86 & 49.25 & 37 & 296 & 0.130 & 0.075 & 0.056 \\
\hline \multirow{5}{*}{$\frac{?}{o}$} & 5.44 & 3.12 & 2.32 & 60 & 25 & 50 & 1370 & 786 & 584 & 6280 & 2.775 & 1.592 & 1.184 \\
\hline & 2.72 & 1.56 & 1.16 & 60 & 25 & 50 & 685 & 393 & 292 & 3140 & 1.388 & 0.796 & 0.592 \\
\hline & 1.36 & 0.78 & 0.58 & 60 & 25 & 50 & 343 & 197 & 146 & 1572 & 0.694 & 0.398 & 0.296 \\
\hline & 0.68 & 0.39 & 0.29 & 60 & 25 & 50 & 172 & 98.5 & 73 & 788 & 0.347 & 0.199 & 0.148 \\
\hline & 0.34 & 0.195 & 0.145 & 60 & 25 & 50 & 86 & 49.25 & 37 & 394 & 0.174 & 0.099 & 0.074 \\
\hline \multirow{5}{*}{ 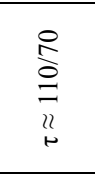 } & 8.16 & 4.68 & 3.48 & 40 & 25 & 50 & 1370 & 786 & 584 & 9420 & 4.163 & 2.387 & 1.775 \\
\hline & 4.08 & 2.34 & 1.74 & 40 & 25 & 50 & 685 & 393 & 292 & 4710 & 2.082 & 1.194 & 0.888 \\
\hline & 2.04 & 1.17 & 0.87 & 40 & 25 & 50 & 343 & 197 & 146 & 2355 & 1.041 & 0.596 & 0.444 \\
\hline & 1.02 & 0.586 & 0.435 & 40 & 25 & 50 & 172 & 98.5 & 73 & 1177 & 0.520 & 0.296 & 0.22 \\
\hline & 0.51 & 0.293 & 0.218 & 40 & 25 & 50 & 86 & 49.25 & 37 & 589 & 0.26 & 0.149 & 0.111 \\
\hline \multirow{5}{*}{ 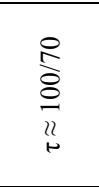 } & 10.87 & 6.24 & 4.63 & 30 & 25 & 50 & 1370 & 786 & 584 & 12560 & 5.546 & 3.183 & 2.362 \\
\hline & 5.44 & 3.12 & 2.32 & 30 & 25 & 50 & 685 & 393 & 292 & 6280 & 2.775 & 1.592 & 1.181 \\
\hline & 2.72 & 1.56 & 1.16 & 30 & 25 & 50 & 343 & 197 & 146 & 3140 & 1.388 & 0.796 & 0.591 \\
\hline & 1.36 & 0.78 & 0.58 & 30 & 25 & 50 & 172 & 98.5 & 73 & 1570 & 0.694 & 0.398 & 0.296 \\
\hline & 0.68 & 0.39 & 0.29 & 30 & 25 & 50 & 86 & 49.25 & 37 & 785 & 0.347 & 0.199 & 0.148 \\
\hline
\end{tabular}




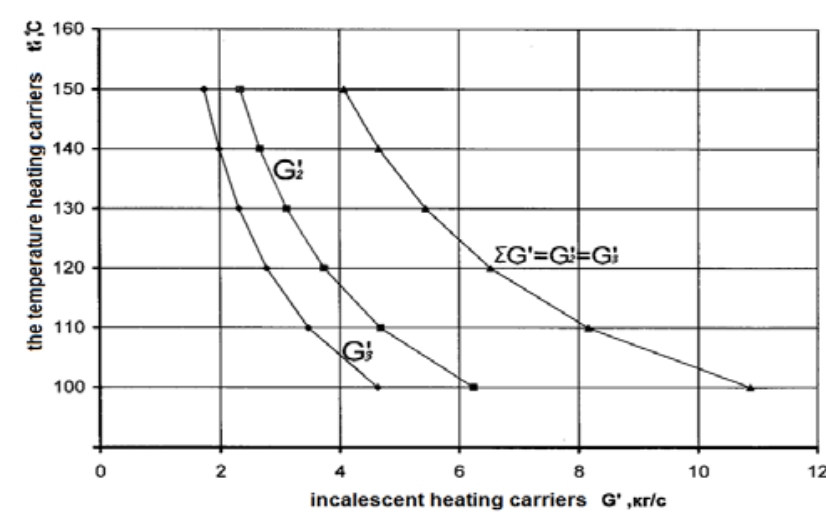

Figure 6 - The heating and hot water supply consumption of the premier heat carrier

\section{DISCUSSION}

We will show the calculating method of the MHUT constructive parameters, which has been built in the form of the experimental model, by the example of the energetic balance check.

The energetic balance can be written in the form of the equation:

$$
Q_{1}^{\prime}=Q_{2}^{\prime}+Q_{3}^{\prime}+Q_{T \Pi}
$$

where $Q_{2}^{\prime}$ - is the heat quantity, transferred by the premier heat carrier into the heating system

$$
Q_{2}^{\prime}=G_{2}^{\prime} \cdot C_{p 2}\left(\tau_{1}^{\prime}+\tau_{2}^{\prime}\right)
$$

$Q_{3} \quad$ - is the heat quantity, transferred by the premier heat carrier into the hot water supply system

$$
Q_{3}^{\prime}=G_{3}^{\prime} \cdot C_{p 3}\left(\tau_{1}^{\prime}+\tau_{3}^{\prime}\right) \text {, }
$$

$Q_{T \Pi}$ - is the heat losses into the environment

$$
Q_{T \Pi}=0.01 Q_{1} \text {. }
$$

It is easy to make sure, that the heating and hot water supply consumption of the premier heat carrier, obtained at the experiments carrying out (table 1) and the ones presented in the fig. 6, coincide with the computation data, calculated from the formulae (27)-(30).

Moreover, on the carried out experiments results basis, the MHUT heating calculation nomogram presented in the fig. 7 has been built. The heating calculation nomogram allows choosing the MHUT construction optimal parameters, i.e. heat-exchanging surface value correlation to the tank-accumulator capacity.

The heat exchanger construction, at which the input and output sockets of the premier heat carrier are placed tangentially to the heat exchanger frame (Fig. 3), assists in turbulization of the flow around the heat exchanging surfaces of the heating and hot water supply system, which improves the heat exchange. The secondary heat carrier in the coil moves in the reverse flow to the premier heat carrier, settled in the intertube space, which contributes to the heat exchanger warming surfaces cleaning and prevents solid suspended particles concretion on their surfaces.

Using nomogram greatly reduces time spent on the MHUT calculation and projection stage and its optimal size choice - the tank-accumulator construction and the coils heating surface.

\section{CONCLUSION}

The MHUT basic constructive parameters calculation method described in the article and the nomogram allow choosing the optimal MHUT construction depending on the exploitation conditions. For the effective practical exploitation of the regarded AHSS, the algorithms of the energy resources optimization in the fixed and non-fixed MHUT work regimes are processed. The experiments carried out on the MHUT full-sized model created by the authors totally confirm the correctness of the obtained theoretical results.

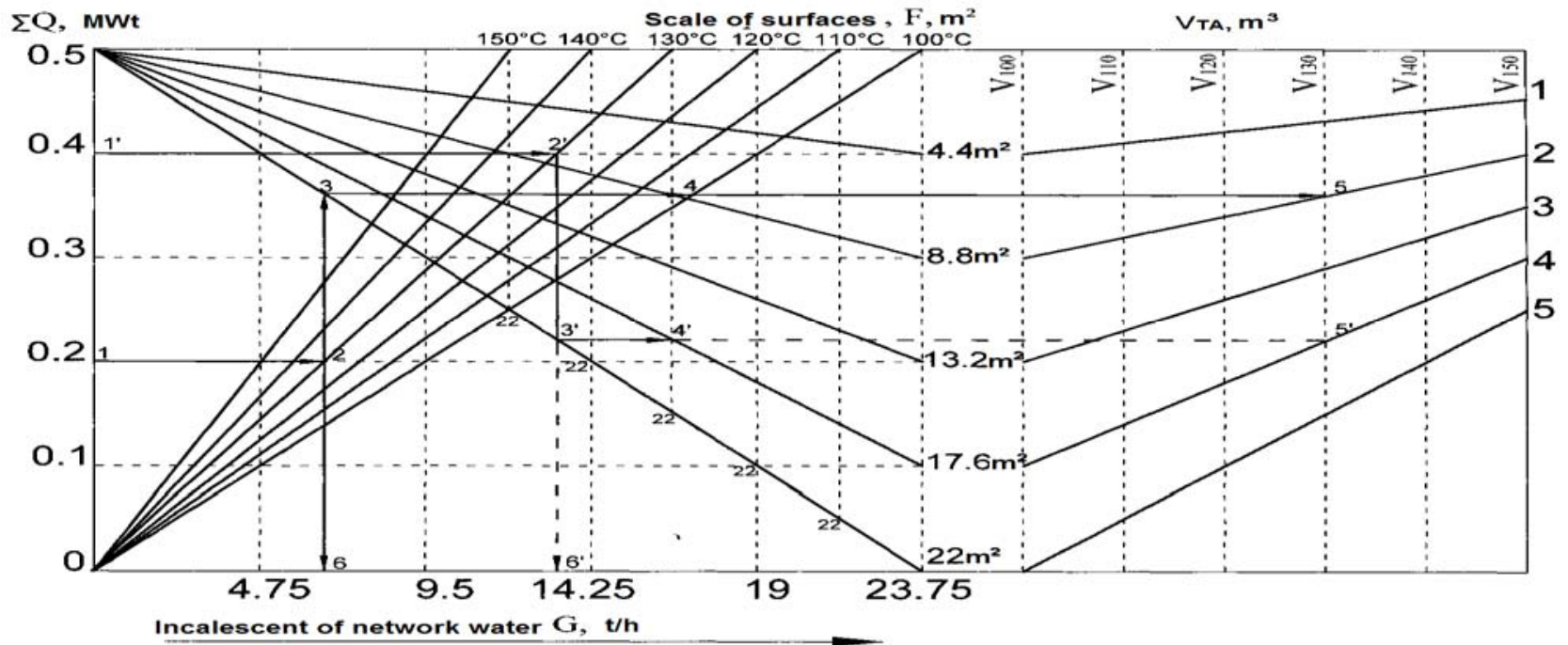

Figure 7 - MHUT heating calculation nomogram

(C) Stenin A., Pas'ko V., Drozdovych I., 2018

DOI 10.15588/1607-3274-2018-3-9 


\section{REFERENCES}

1. Pat. 81831, Ukraïna, MPK F24D 11/00/ Bagatokonturnij teploobminnij aparat zmicvikovogo tipu dlja nezalezhnih sistem opalennja ta garjachogo vodopostachannja / A. O. Oleksjuk, I. G. Shitikova. (Ukraïna); zajavnik Donbas'ka nac.akad.bud. ta arh. - 04.02.2013; opubl. 10.07.2013, Bjul.№13.

2. Aljamovskij A. A., Sobachkin A. A., Odincov E. V., Haritonovich A. I., N. B. Ponomarev Komp'juternoe modelirovanie $\mathrm{V}$ inzhenernoj praktike. Sankt-Peterburg, BHV-Peterburg, 2008, $1040 \mathrm{p}$.

3. Mih€€v M. A., Mih€€va I. M. Osnovi teploperedachi M.A.Mih€€v, Moscow, Vishha shkola, 1977, 336 p.

4. Levchenko B. O., Akmen R. G., Bratuta Je. G. ta in. Teplo- i masoobminni aparati i ustanovki promislovih pidpriemstv. Harkiv, HGPU, 1999, 420 p.

5. Vasilenko S. M., Shutjuk V. V. Teploobminni aparati. Osnovi rozrahunku ta viboru. Kiyv, UDUHT, 2000, 36 p.

6. Oleksjuk A. A., Trofimchuk A. M., Shitikova I. G. Dinamicheskie harakteristiki podogrevatel'no- akkumuljatornyh, Obchisljuval'na i prikladna matematika. 2016, No. 1(121), pp. 78-88.

7. Solonin V. I., Satin A. A. Modelirovanie teploobmena v zmeevikovom teploobmennike primenitel'no $\mathrm{k}$ reaktornoj ustanovke "UNITERM", Nauka i Obrazovanie. MGTU im. N. Je. Baumana., Rossija, Moscow: Setevoe nauchnoe izdanie, 2014, No. 10, pp. 398-412. ISSN 1994-0448. DOI: $10.7463 / 1014.0727220$.

8. Stenin O. A., Pas'ko V. P., Homenko P. S. Metod fiktivnoï koordinati $\mathrm{v}$ zadachah optimal'nogo upravlinnja sistemami z pisljadieju, Adaptivni sistemi avtomatichnogo upravlinnja, 2012, No. 20(40), pp. 116-122.

9. Temam R. Uravnenija Nav'e-Stoksa. Teorija i chislennyj analiz. Moscow, Izdatel'stvo "Mir", 1981, 408 p.

10. Michael Athans, Peter L. Falb Optimal Control: An Introduction to the Theory and Its Applications. New York, McGraw-hill book company, 2006, 879 p.

Received 18.04.2018. Accepted 22.05.2018

\section{УДК 536.24.08}

\section{ПРОЕКТУВАННЯ АВТОНОМНИХ СИСТЕМ ТЕПЛОПОСТАЧАННЯ ТА ОПТИМІЗАЦІЯ ЕНЕРГЕТИЧНИХ РЕСУРСІВ ПРИ ЇХ ЕКСПЛУАТАЦІї}

Стенін А. А. - д-р техн. наук, професор кафедри технічної кібернетики, Київський політехнічний інститут ім. Ігоря Сікорського, Київ, Україна.

Пасько В. П. - канд. техн. наук, доцент кафедри технічної кібернетики, Київський політехнічний інститут ім. Ігоря Сікорського, Київ, Україна.

Дроздович І. Г. - канд. техн. наук, науковий співробітник, Інститут телекомунікацій і глобального інформаційного простору НАН України, Київ, Україна.

\section{АНОТАЦЯ}

Актуальність. Для вирішення більшості завдань, які стоять перед житлово-комунальним господарством країни, необхідно створити і впровадити нові ефективні енергоресурсозберігаючі технології і установки, розробка яких дозволить вирішити проблему зменшення витрат теплоти і металоємності при застосуванні в системах централізованого теплопостачання індивідуальних теплових пунктів.

Мета. Підвищення ефективності роботи автономних систем теплопостачання для об'єктів житлово-комунального господарства. Забезпечення результативних засобів аналізу складних систем і процесів в багатоконтурних теплообмінних апаратах для систем опалення та гарячого водопостачання.

Метод. Для досягнення поставленої задачі був застосований системний підхід до аналізу теплових та гідравлічних процесів, що протікають в автономних систем теплопостачання, і моделювання теплообмінних процесів в багатоконтурних теплообмінних апаратах. Для вирішення крайової задачі запропонована ітераційна процедура. На дослідноекспериментальному стенді провидить дослідження моделі, отримані експериментальні дані.

Результати. Теоретично і експериментально встановлені залежності витрати теплоносія в контурах від кількісті теплоти. Розроблена ітераційна процедура. На основі дослідно-експериментального стенду були проведені дослідження. За результатами проведених експериментів була побудована номограма теплового розрахунку багатоконтурного теплообмінного апарату.

Висновки. Проведені на створеному авторами дослідно-експериментальному стенді багатоконтурного теплообмінного апарату експерименти повністю підтверджують коректність отриманих теоретичних результатів і дають ефективний інструмент для побудови промислових зразків.

КЛЮЧОВІ СЛОВА: автономна система теплопостачання, теплообмінники змієвикового типу, бак-акумулятор, базові конструктивні параметри, оптимізація енергоресурсів, дослідно-експериментальний стенд.

УДК 536.24 .08

\section{ПРОЕКТИРОВАНИЕ АВТОНОМНЫХ СИСТЕМ ТЕПЛОСНАБЖЕНИЯ И ОПТИМИЗАЦИЯ ЭНЕРГЕТИЧЕСКИХ РЕСУРСОВ ПРИ ИХ ЭКСПЛУАТАЦИИ}

Стенин А. А. - д-р техн. наук, профессор кафедры технической кибернетики, Киевский политехнический институт им. Игоря Сикорского, Киев, Украина.

Пасько В. П. - канд. техн. наук, доцент кафедры технической кибернетики, Киевский политехнический институт им. Игоря Сикорского, Киев, Украина. 
Дроздович И. Г. - канд. техн. наук, научный сотрудник, Институт телекоммуникаций и глобального информационного пространства НАН Украины, Киев, Украина.

\section{АННОТАЦИЯ}

Актуальность. Для решения большинства задач, которые стоят перед жилищно-коммунальным хозяйством страны, необходимо создать и внедрить новые эффективные энергоресурсосберегающих технологии и установки, разработка которых позволит решить проблему уменьшения расхода теплоты и металлоемкости при применении в системах централизованного теплоснабжения индивидуальных тепловых пунктов.

Цель. Повышение эффективности работы автономных систем теплоснабжения (АСТС) для объектов жилищнокоммунального хозяйства. Обеспечение результативных средств анализа сложных систем и процессов в многоконтурных теплообменных аппаратах для систем отопления и горячего водоснабжения.

Метод. Для достижения поставленной задачи был применен системный подход к анализу тепловых и гидравлических процессов, протекающих в автономных системах теплоснабжения, и моделированию теплообменных процессов в многоконтурных теплообменных аппаратах. Для решения краевой задачи предложена итерационная процедура. На опытноэкспериментальном стенде проведены исследования модели, получены экспериментальные данные.

Результаты. Теоретически и экспериментально установлены зависимости расхода теплоносителя в контурах от количества теплоты. Разработана итерационная процедура. На основе опытно-экспериментального стенда были проведены исследования. По результатам проведенных экспериментов была построена номограмма теплового расчета многоконтурного теплообменного аппарата.

Выводы. Проведенные на созданном авторами опытно-экспериментальном стенде многоконтурного теплообменного аппарата эксперименты полностью подтверждают корректность полученных теоретических результатов и дают эффективный инструмент для построения промышленных образцов.

КЛЮЧЕВЫЕ СЛОВА: автономная система теплоснабжения, теплообменники змеевикового типа, бак-аккумулятор, базовые конструктивные параметры, оптимизация энергоресурсов, опытно-экспериментальный стенд.

\section{ЛІТЕРАТУРА / ЛИТЕРАТУРА}

1. Пат. 81831, Україна, МПК F24D 11/00/ Багатоконтурний теплообмінний апарат змієвикового типу для незалежних систем опалення та гарячого водопостачання / А. О. Олексюк, И. Г. Шитикова. (Україна); заявник Донбаська нац.акад.буд. та арх. 04.02.2013; опубл. 10.07.2013, Бюл. № 13.

2. Компьютерное моделирование в инженерной практике [А. А. Алямовский, А. А. Собачкин, Е. В. Одинцов, А. И. Харитонович, Н. Б. Пономарев.]. - СанктПетербург : БХВ-Петербург, 2008. - 1040 с.

3. Міхєєв М. А. Основи теплопередачі / М. А. Міхєєв, И. М. Міхєєва. - М. : Вища школа, 1977. - 336 с.

4. Тепло- і масообмінні апарати і установки промислових підприємств [Левченко Б. О., Акмен Р. Г., Братута Э. Г. та ін.]. - Харків : ХГПУ, 1999. - 420 с.

5. Василенко С. М. Теплообмінні апарати. Основи розрахунку та вибору / С. М. Василенко, В. В. Шутюк. К. :УДУХТ, 2000. - $36 \mathrm{c.}$

6. Шитикова И. Г. Динамические характеристики подогревательно-аккумуляторных установок / А. А. Олексюк, А. М. Трофимчук, И. Г. Шитикова //
Обчислювальна і прикладна математика. - 2016. №1(121). - С. 78-88.

7. Солонин В. И. Моделирование теплообмена в змеевиковом теплообменнике применительно к реакторной установке «УНИТЕРМ» / В. И. Солонин, А. А. Сатин // Наука и Образование. МГТУ им. Н. Э. Баумана, Россия, Москва: Сетевое научное издание. - 2014. - № 10. - С. 398-412. ISSN 1994-0448. DOI:10.7463/1014.0727220.

8. Стенін О. А. Метод фіктивної координати в задачах оптимального управління системами 3 післядією / О. А. Стенін, В. П. Пасько, П. С. Хоменко // Адаптивні системи автоматичного управління. - 2012 . № 20(40). - C. 116-122.

9. Темам Р. Уравнения Навье-Стокса. Теория и численный анализ / Р. Темам. - М. : Издательство «Мир», 1981. $408 \mathrm{c}$.

10. Michael Athans. Optimal Control: An Introduction to the Theory and Its Applications / Michael Athans Peter L. Falb. - New York : McGraw-hill book company, 2006 $879 \mathrm{p}$. 